\title{
Hyperinsulinaemia, dyslipidaemia and exaggerated adrenal androgen response to adrenocorticotropin in male smokers
}

\author{
A.Hautanen, H. Adlercreutz \\ Department of Clinical Chemistry, University of Helsinki, Helsinki, Finland
}

\begin{abstract}
Summary. Insulin resistance and dyslipidaemia associated with smoking may result from increased secretion of anti-insulin hormones. We compared the pituitary-adrenocortical function using oral glucose tolerance, dexamethasone suppression and ACTH stimulation tests in smoking $(n=22)$ and non-smoking $(n=22)$ healthy males matched for age, body mass index, and waist-to-hip ratio. Smokers had lower HDL-cholesterol $(p<0.02)$, and higher triglyceride $(p<0.001)$, basal cortisol $(p<0.05)$, insulin $(p<0.05)$, and C-peptide $(p<0.02)$ levels, and a higher response of insulin and C-peptide to oral glucose $(p<0.005)$ than non-smokers, while the ACTH, cortisol, 17-hydroxyprogesterone, dehydroepiandrosterone, and androstenedione responses to oral glucose were similar in both groups. No differences were found in the response of cortisol, 17-hydroxyprogesterone, dehydroepiandrosterone, and androstenedione to dexa-
\end{abstract}

methasone. In contrast, the response of 17 -hydroxyprogesterone $(p=0.04)$, dehydroepiandrosterone $(p=0.007)$, and androstenedione $(p=0.001)$ to ACTH was higher in smokers than non-smokers, while the increase in cortisol was of marginal significance $(p=0.07)$. In multiple regression analyses the dehydroepiandrosterone response to ACTH was a significant determinant of insulin, C-peptide, and triglyceride levels independent of physical activity, waist-to-hip ratio and HDL-cholesterol. Thus, smoking inhibits the adrenal 21-hydroxylase resulting in an increase in the production of adrenal androgens, which might contribute to the insulin resistance and dyslipidaemia in smokers.

Key words: Insulin resistance, C-peptide, lipoproteins, obesity, dehydroepiandrosterone, androstenedione, 17-hydroxyprogesterone, cortisol.
Smoking, a major risk factor for coronary heart disease (CHD) [1], may be associated with insulin resistance and hyperinsulinaemia [2]. The decrease in serum HDL-cholesterol (HDLC) and the increase in triglyceride (TG) levels [3] may be secondary to insulin resistance [4]. Other hormonal abnormalities in smokers include elevated dehydroepiandrosterone sulphate (DHEAS), androstenedione, cortisol, growth hormone and catecholamines [5-13]. The last three hormones can antagonize many of the insulin effects, and may thus be involved in causing insulin resistance [14-16]. We have been interested in the hypothesis that an altered neuroendocrine response via the pituitary-adrenal axis may have a role in inducing insulin resistance and dyslipidaemia [17]. To examine this possibility further, we carried out oral glucose tolerance tests (OGTT) followed by dexamethasone suppression and ACTH stimulation tests on wellmatched groups of healthy smokers and non-smokers. The response to oral glucose of insulin, C-peptide, ACTH, cortisol, 17-hydroxyprogesterone (17-OHP), dehydroepiandrosterone (DHEA), and androstenedione, and the response of adrenocortical steroids to dexamethasone (DXM) and ACTH were compared between the groups.

\section{Subjects and methods}

\section{Subjects}

This study is part of a research project, which addressed the hypothetical associations between the psychological and behavioural characteristics, life-style factors, neuroendocrine responses, and the insulin resistance syndrome. Non-physician acquaintances in various companies, trade unions, and sports societies recruited their collegues to volunteer for this project. Potential participants were allowed to read a lay version of the research plan, which described the methods and the purpose of the study. The plan included the information that smoking may alter the lipoprotein and hormone patterns. Altogether 101 men agreed to participate. The study protocol was approved by the local ethics committee.

Of the 101 men, 25 had hypertension, 1 diabetes, 4 coronary heart disease, and 5 reported ethanol use of more than $400 \mathrm{~g} /$ week. The remaining 66 healthy subjects included 26 smokers, of whom 23 
Table 1. Characteristics of the study groups

\begin{tabular}{|c|c|c|c|}
\hline \multirow[t]{2}{*}{ Variable } & Non-smokers & Smokers & \multirow[b]{2}{*}{$p$ value } \\
\hline & $\begin{array}{l}\text { Mean (SD) } \\
\text { Range }\end{array}$ & $\begin{array}{l}\text { Mean (SD) } \\
\text { Range }\end{array}$ & \\
\hline Age (years) & $\begin{array}{l}44.4(5.1) \\
34-53\end{array}$ & $\begin{array}{l}43.7(5.7) \\
30-52\end{array}$ & 0.659 \\
\hline Height $(\mathrm{cm})$ & $\begin{array}{l}180(5.4) \\
170-190\end{array}$ & $\begin{array}{l}180.5(5.9) \\
171-197\end{array}$ & 0.671 \\
\hline Weight (kg) & $\begin{array}{l}80.9(10.5) \\
67-105\end{array}$ & $\begin{array}{l}81.9(12.7) \\
66-113\end{array}$ & 0.787 \\
\hline $\begin{array}{l}\text { Body mass index } \\
\left(\mathrm{kg} / \mathrm{m}^{2}\right)\end{array}$ & $\begin{array}{l}25.0(2.4) \\
22.0-30.1\end{array}$ & $\begin{array}{l}25.0(2.8) \\
20.2-30.2\end{array}$ & 0.947 \\
\hline Waist circumference $(\mathrm{cm})$ & $\begin{array}{l}88.5(7.0) \\
75-103\end{array}$ & $\begin{array}{l}91.3(9.9) \\
71-112\end{array}$ & 0.299 \\
\hline Hip circumference $(\mathrm{cm})$ & $\begin{array}{l}96.3(5.6) \\
86-110\end{array}$ & $\begin{array}{l}97.5(5.4) \\
88-107\end{array}$ & 0.465 \\
\hline Waist-to-hip ratio & $\begin{array}{l}0.92(0.05) \\
0.81-1.04\end{array}$ & $\begin{array}{l}0.93(0.06) \\
0.78-1.08\end{array}$ & 0.415 \\
\hline $\begin{array}{l}\text { Systolic blood pressure } \\
(\mathrm{mm} \mathrm{Hg})\end{array}$ & $\begin{array}{l}121(9) \\
94-134\end{array}$ & $\begin{array}{l}121(10) \\
104-138\end{array}$ & 0.879 \\
\hline $\begin{array}{l}\text { Diastolic blood pressure } \\
(\mathrm{mm} \mathrm{Hg})\end{array}$ & $\begin{array}{l}77(8) \\
62-88\end{array}$ & $\begin{array}{l}77(7) \\
64-88\end{array}$ & 0.900 \\
\hline Alcohol (g/week) & $\begin{array}{l}170(127) \\
0-400\end{array}$ & $\begin{array}{l}168(99) \\
0-400\end{array}$ & 0.937 \\
\hline Cigarettes (number/day) & $\begin{array}{l}0(0) \\
0\end{array}$ & $\begin{array}{l}18.8(8.1) \\
5-35\end{array}$ & 0.000 \\
\hline Physical activity index & $\begin{array}{l}2.50(0.67) \\
1-3\end{array}$ & $\begin{array}{l}2.10(0.44) \\
1-3\end{array}$ & 0.025 \\
\hline
\end{tabular}

Two-tailed $p$ values less than 0.05 are statistically significant

had provided 12-h urine samples. For this study, 22 smokers and 22 non-smokers, carefully matched for age, body mass index (BMI) and waist-to-hip circumference ratio (WHR), were selected. The selection was based on the matching criteria stated, and on the availability of 12-h urine samples for the determination of oestrogen profiles (Hautanen and Adlercreutz, unpublished data). They were receiving no medication and had no history or clinical evidence of liver, kidney, gastrointestinal, endocrine or coronary heart disease, as determined by clinical examination, and laboratory analyses, which included blood cell counts, serum chemistry profiles, urinalyses and electrocardiograms.

Alcohol consumption,physical activity, and smoking were estimated by a standard questionnaire completed by personal interview. Physical exercise was denied, but smoking was allowed during the study period, because one of the original goals of the project was toinvestigate the effects of chronic smoking on oestrogen metabolism. The exact amount smoked during the early morning hours preceding the OGTT and ACTH tests was not asked. Thus, we cannot distinguish between the acute and chronic effects of smoking on the test results.

Three categories of leisure-time exercise patterns were used: 1) no regular physical activity, 2) light physical activity, 3) moderate to strenuous physical activity. The smoking group consisted of 1 cigar smoker, 4 cigarillo smokers, 1 pipe smoker, and 16 cigarette smokers. One cigar was considered to be equivalent to 4 cigarettes, one cigarillo to 2 cigarettes, and one pipeful to 2.5 cigarettes. Table 1 shows the characteristics of the subjects.

\section{Study protocol}

Studies were carried out on three consecutive days at the Helsinki University Central Hospital. On day 1, at 07.30 hours blood samples were drawn to determine blood cell counts and serum chemistry profiles including cholesterol, TG and HDLC followed by recording of electrocardiograms. Starting at 18.00 hours, 12 -h urine was collected (subject number 16 being the first with urine sample in this series). On day 2 , at 07.30 hours, an OGTT was carried out. An indwelling cannula was inserted into an antecubital vein, after $30 \mathrm{~min}$ a standard 75-g glucose dose was given. Blood samples were drawn through the cannula at 0,60 and $120 \mathrm{~min}$ after the glucose dose for the determination of insulin, C-peptide, glucose, ACTH, cortisol, 17-OHP, DHEA, and androstenedione.

On day 2 , each subject received $1 \mathrm{mg}$ of DXM orally at 23.00 hours. On day 3 at 07.30 hours, an indwelling catheter was inserted into an antecubital vein, after $30 \mathrm{~min} 10 \mu \mathrm{g} / \mathrm{m}^{2}$ of $\mathrm{ACTH}$ was injected intravenously. Blood was sampled $-30,0,30$ and $60 \mathrm{~min}$ after the administration of ACTH for the determination of serum cortisol, 17-OHP, DHEA, and androstenedione concentrations. All blood samples were collected after a 12 -h fast.

\section{Procedures}

The smallest girth between the rib cage and iliac crest and the largest girth between the waist and thigh were defined as the waist and hip circumferences, respectively. BMI was calculated as weight $(\mathrm{kg})$ divided by height (m) squared.

Systolic and diastolic blood pressures were measured by a standard sphygmomanometer on days 2 and 3 before the glucose tolerance and ACTH tests. The subjects had been in the supine position for at least $15 \mathrm{~min}$. Three readings to the nearest even digit were recorded, and the mean of the second and third readings was defined as the blood pressure. If the blood pressure exceeded the limits defined previously [18] on both days the subject was considered to have hypertension and excluded from this analysis.

\section{Analytical procedures}

Total cholesterol was measured by the CHOD-PAP and TG by the GPO-PAP method (Boehringer Mannheim GmbH, Mannheim, Germany) $[19,20]$. HDLC was determined after precipitation of very low density lipoproteins (VLDL) and LDL with dextran sulphate-magnesium chloride [21].

Commercial RIA kits were used for the determination of cortisol (Farmos Diagnostica, Oulu, Finland), insulin, (Pharmacia, Uppsala, Sweden), and C-peptide (Byk-Sangtec Diagnostica GmbH, Dietzenbach, Germany). Intact ACTH was determined by procedure A of the double-antibody RIA (Incstar Corp., Stillwater, Minn., USA).

Androstenedione, DHEA and 17-OHP were determined by RIA essentially as described $[22,23]$. Antisera for DHEA and 17OHP were purchased from Radioassay Systems Laboratories (Carson, Calif., USA) and for androstenedione from Steranti Research Ltd. Co. (St. Albans, Herts., UK). For the measurement of DHEA, $25 \mu \mathrm{l}$ of serum was diluted with $175 \mu 1$ buffer, extracted once with $2 \mathrm{ml}$ of petroleum ether (b.p. $40-60^{\circ} \mathrm{C}$ ) and determined by RIA using a final dilution of antiserum of $1: 45000$. Dehydro[1,2,6,7- $\left.{ }^{3} \mathrm{H}\right]$ epiandrosterone (Amersham, Bucks., UK, code TRK 511) was used as label. For the determination of $17-\mathrm{OHP}, 50 \mu \mathrm{l}$ of serum was diluted with $150 \mu$ of buffer, and extracted once with $1.5 \mathrm{ml}$ of a $1: 2$ mixture of diethylether-petroleum ether. The final dilution of the antiserum in this case was $1: 30000$ and the label used was 17-hydroxy $\left[1,2,6,7,{ }^{3} \mathrm{H}\right]$ progesterone (Amersham, code TRK 611).

Means of duplicate determinations were used in all calculations. High- and low-value quality control samples were included in each assay. Samples were re-run, if duplicate values differed more than $10 \%$ from their calculated mean. The within-assay and between assay imprecision (CV) of the RIA methods were as follows: cortisol 6.4 and $7.0 \%, 17$-OHP 6.1 and $9.2 \%$, DHEA 3.0 and $5.8 \%$, androstenedione 4.8 and $6.1 \%$, insulin 5.1 and $7.5 \%$, C-peptide 4.1 and $9.5 \%$, respectively. For ACTH CVs varied from 3.4 and $23.1 \%$ (low control values) to 4.2 and $7.1 \%$ (high control values). 
Table 2. Cortisol, ACTH, insulin, glucose, and C-peptide responses during oral glucose tolerance test in non-smokers and smokers

\begin{tabular}{|c|c|c|c|}
\hline \multirow[t]{2}{*}{ Variable } & Non-smokers & \multicolumn{2}{|l|}{ Smokers } \\
\hline & Mean (SD) & $\operatorname{Mean}(\mathrm{SD})$ & $p$ value \\
\hline \multicolumn{4}{|c|}{ Cortisol (nmol/l) } \\
\hline Basal & $362 \quad(74)$ & $419(87)$ & 0.023 \\
\hline 2-h & $325 \quad(93)$ & $285(89)$ & 0.151 \\
\hline Sum & $999 \quad(194)$ & $1027(187)$ & 0.626 \\
\hline \multicolumn{4}{|c|}{$A C T H(n g / l)$} \\
\hline Basal & $13.2(4.0)$ & $15.5(6.9)$ & 0.170 \\
\hline $2-\mathrm{h}$ & $13.1 \quad(3.9)$ & $12.7(3.6)$ & 0.718 \\
\hline Sum & $40.5 \quad(12.6)$ & $42.8(13.8)$ & 0.572 \\
\hline \multicolumn{4}{|c|}{ Insulin $(m U / l)$} \\
\hline Fasting & $5.4 \quad(2.9)$ & $9.5(8.3)$ & 0.036 \\
\hline $2-h$ & $27.0 \quad(17.4)$ & $54.1(38.1)$ & 0.004 \\
\hline Sum & $71.5 \quad(31.7)$ & $137.3(85.2)$ & 0.002 \\
\hline \multicolumn{4}{|c|}{ Glucose (mmol/l) } \\
\hline Fasting & $3.28(0.34)$ & $3.23(0.36)$ & 0.670 \\
\hline $2-h$ & $3.66(0.95)$ & $3.94(0.85)$ & 0.305 \\
\hline Sum & $11.54(2.24)$ & $12.9(1.85)$ & 0.033 \\
\hline \multicolumn{4}{|c|}{ C-peptide $($ nmolll $)$} \\
\hline Fasting & $0.56(0.20)$ & $0.79(0.37)$ & 0.012 \\
\hline 2-h & $1.98(0.79)$ & $2.98(1.08)$ & 0.001 \\
\hline Sum & $4.72(1.47)$ & $6.79(2.07)$ & 0.000 \\
\hline
\end{tabular}

\section{Statistical analysis}

Differences between the groups were tested by the Student's $t$-test. Pearson correlation coefficients were computed, and multiple linear regression analyses carried out with the Systat statistical program package. Logarithmic transformations for TG, insulin, and the cortisol response to DXM were used to normalize the distributions.

\section{Results}

As shown in Table 1, non-smokers and smokers were closely matched for age, BMI and WHR. Non-smokers were physically more active than smokers. Systolic and diastolic blood pressures did not differ between the groups.

Non-smokers had higher HDLC $(1.30 \pm 0.32$ vs $1.09 \pm 0.25 \mathrm{mmol} / \mathrm{l} ; p=0.019)$ and lower TG $(0.97 \pm 0.38$ vs $1.64 \pm 0.79 \mathrm{mmol} / 1 ; p=0.001$ ) concentrations than smokers, but no significant difference was found in cholesterol levels $(5.15 \pm 0.92$ vs $5.47 \pm 1.02 \mathrm{mmol} / 1 ; p=0.277)$.

Cortisol, ACTH, insulin, glucose, and C-peptide responses during the OGTT are presented in Table 2. Smokers had higher basal cortisol than non-smokers, but similar cortisol and ACTH response to oral glucose. Fasting insulin and C-peptide concentrations and their response to oral glucose were significantly higher in smokers compared with non-smokers. Smokers had a higher 1-h glucose response $(p<0.012$, not shown) and a higher total glucose response than non-smokers. All subjects had normal glucose tolerance. Some subjects had moderate insulin resistance based on high fasting insulin and C-peptide concentrations and high response to oral glucose.

No differences were seen in the levels of 17-OHP, DHEA and androstenedione during the OGTT. The
Table 3. Basal levels of adrenal steroids and responses to dexamethasone (DXM) suppression and ACTH stimulation in nonsmokers and smokers

\begin{tabular}{|c|c|c|c|}
\hline \multirow[t]{2}{*}{ Variable } & \multirow{2}{*}{$\begin{array}{l}\text { Non-smokers } \\
\text { Mean (SD) }\end{array}$} & \multicolumn{2}{|l|}{ Smokers } \\
\hline & & Mean (SD) & $p$ value \\
\hline \multicolumn{4}{|l|}{ Cortisol (nmolll) } \\
\hline After DXM time 0 & $34(15)$ & $45(44)$ & 0.296 \\
\hline After ACTH time +30 & $492(95)$ & $541(91)$ & 0.068 \\
\hline time +60 & $619(108)$ & $673(103)$ & 0.071 \\
\hline Net response & 1069 (184) & $1169(164)$ & 0.063 \\
\hline \multicolumn{4}{|l|}{ Androstenedione (nmoll) } \\
\hline Basal & $4.3(0.8)$ & $4.5 \quad(0.7)$ & 0.378 \\
\hline After DXM time 0 & $4.8 \quad(0.7)$ & $4.9 \quad(0.7)$ & 0.595 \\
\hline After ACTH time +30 & $5.9(1.4)$ & $6.8(1.5)$ & 0.032 \\
\hline time +60 & $6.0(1.2)$ & $7.3(1.3)$ & 0.001 \\
\hline Net response & $7.1 \quad(2.3)$ & $9.3(2.3)$ & 0.003 \\
\hline \multicolumn{4}{|l|}{$\begin{array}{l}\text { Dehydroepiandrosterone } \\
\text { (nmol/l) }\end{array}$} \\
\hline Basal & $11.5(3.9)$ & $12.8(4.4)$ & 0.292 \\
\hline After DXM time 0 & $4.8 \quad(2.7)$ & $5.4(2.8)$ & 0.491 \\
\hline After ACTH time +30 & $22.1(13.8)$ & $26.6(12.4)$ & 0.257 \\
\hline time +60 & $27.6(14.0)$ & $39.5(15.9)$ & 0.012 \\
\hline Net response & $44.9(25.6)$ & $60.7(25.7)$ & 0.046 \\
\hline \multicolumn{4}{|l|}{$\begin{array}{l}\text { 17-hydroxyprogesterone } \\
\text { (nmol/l) }\end{array}$} \\
\hline Basal & $6.8(2.5)$ & $7.5(2.9)$ & 0.390 \\
\hline After DXM time 0 & $4.8(2.2)$ & $4.8 \quad(2.2)$ & 0.978 \\
\hline After ACTH time +30 & $14.4(3.3)$ & $17.0 \quad(3.1)$ & 0.011 \\
\hline time +60 & $16.2(2.9)$ & $18.5(3.5)$ & 0.022 \\
\hline Net response & $25.8(5.4)$ & $30.7 \quad(6.3)$ & 0.008 \\
\hline
\end{tabular}

Table 4. Pearson's correlations between the ACTH-stimulated steroid responses at $60 \mathrm{~min}$ and the metabolic variables

C-peptide Insulin Trigly- Chole- HDLcerides sterol chole-

sterol

\begin{tabular}{|c|c|c|c|c|}
\hline Cortisol & $0.334^{a}$ & $0.317^{\mathrm{a}}$ & $0.363^{a}$ & $-0.076-0.201$ \\
\hline $\begin{array}{l}\text { Dehydroepiandro- } \\
\text { sterone }\end{array}$ & $0.400^{\mathrm{b}}$ & $0.391^{b}$ & $0.347^{\mathrm{a}}$ & $0.314^{\mathrm{a}}-0.133$ \\
\hline Androstenedione & 0.210 & 0.213 & 0.202 & $-0.048-0.091$ \\
\hline $\begin{array}{l}\text { 17-hydroxy- } \\
\text { progesterone }\end{array}$ & $0.326^{\mathrm{a}}$ & 0.287 & $0.352^{\mathrm{a}}$ & $0.005 \quad 0.161$ \\
\hline
\end{tabular}

${ }^{\mathrm{a}} p<0.05,{ }^{\mathrm{b}} p<0.01$

mean of three measured values (basal level) is shown in Table 3. DXM-suppressed cortisol, 17-OHP, DHEA, and androstenedione were similar in both groups. In contrast to this, the 17-OHP, DHEA, and androstenedione response to ACTH stimulation was higher in smokers than non-smokers, while the increase in the cortisol response was of marginal significance.

The data were pooled for the correlation and multiple regression analyses to increase the statistical power. As shown in Table 4, the cortisol response to ACTH stimulation at $60 \mathrm{~min}$ was positively correlated with fasting $\mathrm{C}$ peptide, insulin and TG concentrations. The DHEA response to ACTH was also positively associated with Cpeptide, insulin, TG and cholesterol concentrations, while the 17-OHP response correlated positively with C-peptide and TG. No significant correlations were found be- 

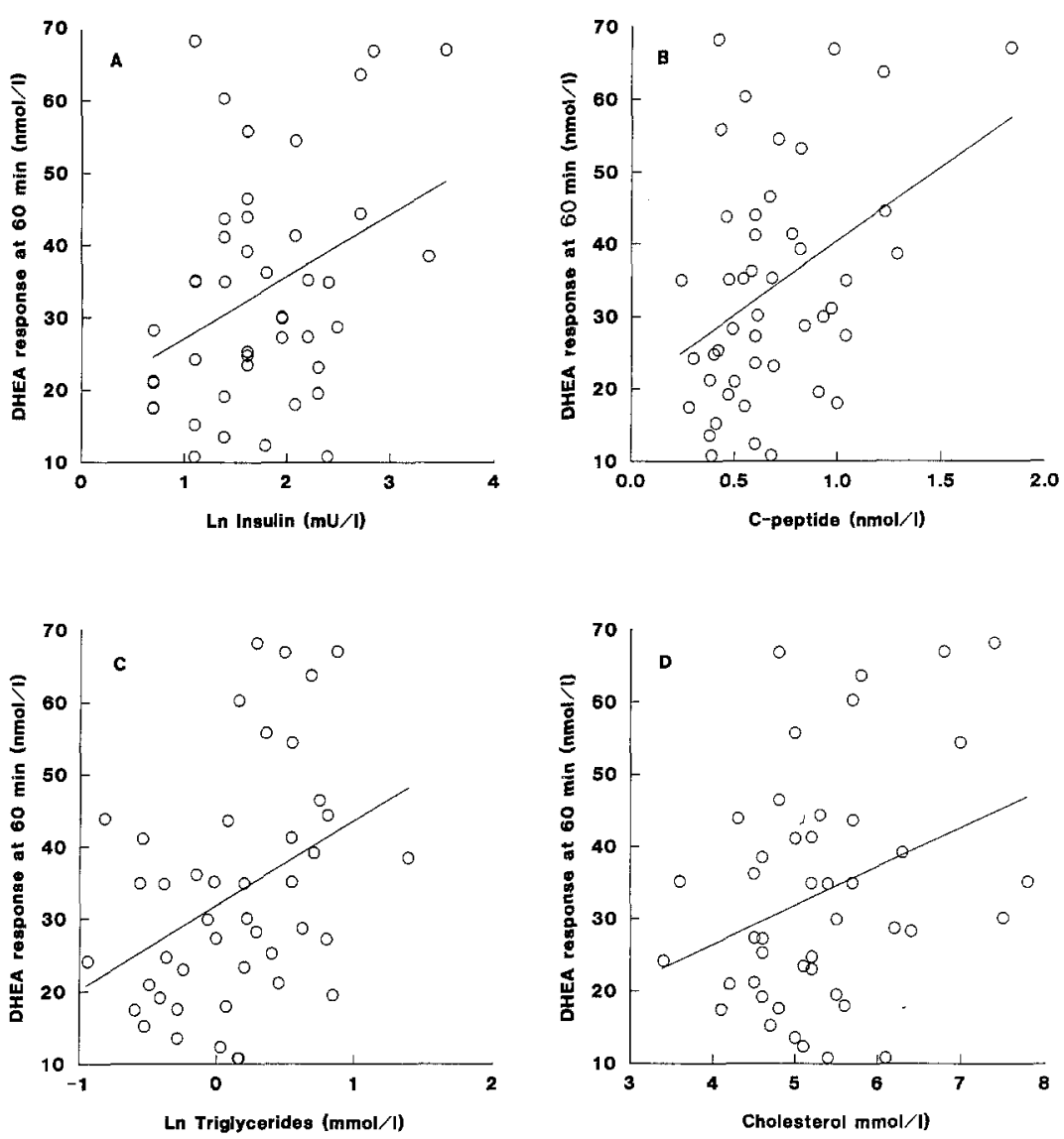

Fig.1A-D. Dehydroepiandrosterone (DHEA) response to ACTH stimulation at 60 min vs fasting insulin (A), C-peptide (B), triglycerides (C), and cholesterol (D)

Table 5. Multiple regression models for the prediction of fasting insulin levels in the study group $(n=44)^{\mathrm{a}}$

\begin{tabular}{llcll}
\hline Model & $\begin{array}{l}\text { Independent } \\
\text { variable(s) }\end{array}$ & $\begin{array}{l}\text { Standardized } \\
\text { coefficient } \\
\text { of regression }\end{array}$ & $\begin{array}{l}p \text { value } \\
\text { (two-tailed) }\end{array}$ & $\begin{array}{l}\text { Model } \\
R^{2 \mathrm{~b}}\end{array}$ \\
\hline 1 & Cortisol $+60^{\mathrm{c}}$ & 0.341 & 0.023 & 0.116 \\
2 & DHEA $+60^{\mathrm{d}}$ & 0.372 & 0.013 & 0.139 \\
3 & Cortisol +60 & 0.388 & 0.006 & 0.287 \\
& DHEA +60 & 0.416 & 0.003 & \\
4 & Cortisol +60 & 0.285 & 0.026 & 0.440 \\
& DHEA +60 & 0.327 & 0.011 & \\
5 & WHR & 0.412 & 0.002 & \\
& Cortisol +60 & 0.219 & 0.085 & 0.489 \\
& DHEA +60 & 0.233 & 0.077 & \\
& WHR & 0.339 & 0.011 & \\
& Triglycerides & 0.265 & 0.062 & 0.541 \\
6 & Cortisol +60 & 0.229 & 0.052 & \\
& DHEA +60 & 0.286 & 0.015 & \\
& WHR & 0.337 & 0.006 & \\
& HDL-Chole- & & & \\
& sterol & -0.337 & 0.006 & \\
\hline
\end{tabular}

DHEA, Dehydroepiandrosterone; WHR, waist-to-hip ratio.

${ }^{a}$ Independent variables in the regression models have been used either alone or in groups as shown to predict the insulin levels.

${ }^{\mathrm{b}} R^{2}$ (the square of the multiple regression coefficient) gives the proportion of the total variation in risk factor levels that is explained by the variables in the model.

${ }^{c}$ ACTH-stimulated cortisol response at $60 \mathrm{~min}$

${ }^{d}$ ACTH-stimulated DHEA response at $60 \mathrm{~min}$ tween the androstenedione response to $\mathrm{ACTH}$ and the metabolic variables stated. The relationships between the DHEA response and insulin, C-peptide, TG, and cholesterol are also illustrated in Figure 1. In addition, physical activity was correlated with HDLC $(r=0.390 ; p=0.009)$ and TG $(r=-0.386 ; p=0.01)$.

Multiple linear regression analyses were used to examine the contribution of the ACTH-stimulated cortisol and DHEA responses to the variation in fasting insulin levels (Table 5). Both the above responses were independent predictors of insulin explaining together $28.7 \%$ of the insulin variation. The explanatory power increased, when WHR alone (Model $R^{2}=0.440$ ) or in combination with either TG (Model $R^{2}=0.489$ ) or HDLC (Model $R^{2}=0.541$ ) were incorporated into the models, but the DHEA response to ACTH remained a significant and independent predictor of insulin levels. Analogous results were obtained when insulin was substituted by fasting Cpeptide as the dependent variable in the models. Addition of either physical activity or smoking or both to these models did not change the result (data not shown).

When TG was used as the dependent variable in the multiple regression analysis, the DHEA response to ACTH explained $14.5 \%$, and the combination of the cortisol and DHEA responses $24.3 \%$ of the variation in the TG levels (Table 6). The significance of the cortisol response decreased, while that of the DHEA response remained, when WHR and HDLC were entered into the models. The combined DHEA response and HDLC explained $31.6 \%$ of the variation in the TG levels. The addi- 
tion of physical activity to these models did not change the significant association between DHEA response and TG. In contrast, when adjusted for smoking, the DHEA response lost its statistical significance as the predictor of TG levels.

Finally, regression analyses were used to predict the smoking status of the study subjects to exclude the potential bias resulting from the tendency for smokers to have higher WHR, but lower weight [17]. As shown in Table 7, the DHEA response to ACTH remained the only significant predictor of smoking, when adjusted for either BMI or WHR, fasting insulin, HDLC, and physical activity. When HDLC was substituted by TG in these models, the smoking status was predicted significantly $(p=0.033)$ by TG in model 1 , and almost significantly $(p=0.071)$ in model 2 , but not by the other variables.

\section{Discussion}

The study participants had been informed that smoking may alter the lipoprotein and hormone patterns. They were allowed to continue their usual smoking habits, because one of the original goals of this project was to investigate the effects of chronic smoking on urinary oestrogens. General smoking history was asked during the OGTT, but not the exact amount of tobacco smoked during the preceding hours. Thus, the lack of control of acute smoking prior to the tests might be one shortcoming of this report. Nevertheless, if a subject classified as smoker came to the tests without antecedent smoking, it is likely that the probability to detect hormonal differences between the two groups is decreased, not increased.

Smoking acutely increases the secretion of major glucose counterregulatory hormones: cortisol, as shown here, and growth hormone, epinephrine, and norepinephrine, as shown by others [10-13]. Consequently, increased Cpeptide secretion, hyperinsulinaemia, and subtle glucose intolerance might have resulted at least partly from the acute effects of smoking. Thus, with respect to glucose and insulin metabolism, this study might well reflect the circumstances in the daily life of smokers. Our results corroborate recent findings which showed that smoking is associated with insulin resistance [2]. They contrast, however, to some extent with another study [24], in which study subjects had abstained from smoking before the examinations. Even in the latter study, impaired elimination of glucose in smokers was found.

Our data suggest that the production of adrenal androgens is increased in smokers probably because of a subtle enzyme blockade in the biosynthesis of cortisol. The adrenal $3 \beta$-hydroxysteroid dehydrogenase $(3 \beta$-HSD), $11 \beta$ and 21 -hydroxylases are the key enzyme systems involved in cortisol biosynthesis. Inhibition of these enzymes leads to increased steroid production proximal to the enzyme blockade. Excess secretion of DHEA results from a deficiency of $3 \beta$-HSD, while 21 - and $11 \beta$-hydroxylase deficiencies lead to an increased secretion of androstenedione [25]. The increased response to ACTH stimulation of DHEA and androstenedione relative to cortisol may thus be explained by a decreased 21 - or $11 \beta$-hydroxylase activ-
Table 6. Multiple regression models for the prediction of the triglyceride levels in the study group $(n=44)^{\text {a }}$

\begin{tabular}{|c|c|c|c|c|}
\hline Model & $\begin{array}{l}\text { Independent } \\
\text { variable(s) }\end{array}$ & $\begin{array}{l}\text { Standardized } \\
\text { coefficient } \\
\text { of regression }\end{array}$ & $\begin{array}{l}p \text { value } \\
\text { (two- } \\
\text { tailed) }\end{array}$ & $\begin{array}{l}\text { Model } \\
R^{2 \mathrm{~b}}\end{array}$ \\
\hline 1 & Cortisol $+60^{\circ}$ & 0.269 & 0.078 & 0.072 \\
\hline 2 & DHEA $+60^{d}$ & 0.380 & 0.011 & 0.145 \\
\hline 3 & $\begin{array}{l}\text { Cortisol }+60 \\
\text { DHEA }+60\end{array}$ & $\begin{array}{l}0.315 \\
0.415\end{array}$ & $\begin{array}{l}0.026 \\
0.004\end{array}$ & 0.243 \\
\hline 4 & $\begin{array}{l}\text { Cortisol + } 60 \\
\text { DHEA + } 60 \\
\text { WHR }\end{array}$ & $\begin{array}{l}0.247 \\
0.357 \\
0.273\end{array}$ & $\begin{array}{l}0.078 \\
0.012 \\
0.055\end{array}$ & 0.310 \\
\hline 5 & $\begin{array}{l}\text { Cortisol }+60 \\
\text { DHEA }+60 \\
\text { WHR } \\
\text { HDL-cholesterol }\end{array}$ & $\begin{array}{r}0.194 \\
0.318 \\
0.202 \\
-0.323\end{array}$ & $\begin{array}{l}0.145 \\
0.018 \\
0.139 \\
0.018\end{array}$ & 0.403 \\
\hline 6 & $\begin{array}{l}\text { DHEA }+60 \\
\text { HDL-cholesterol }\end{array}$ & $\begin{array}{r}0.320 \\
-0.418\end{array}$ & $\begin{array}{l}0.019 \\
0.003\end{array}$ & 0.316 \\
\hline 7 & $\begin{array}{l}\text { DHEA + } 60 \\
\text { WHR } \\
\text { HDL-cholesterol } \\
\text { Physical activity }\end{array}$ & $\begin{array}{r}0.270 \\
0.231 \\
-0.282 \\
-0.201\end{array}$ & $\begin{array}{l}0.039 \\
0.086 \\
0.049 \\
0.145\end{array}$ & 0.403 \\
\hline 8 & $\begin{array}{l}\text { DHEA + } 60 \\
\text { WHR } \\
\text { HDL-cholesterol } \\
\text { Smoking }\end{array}$ & $\begin{array}{r}0.196 \\
0.249 \\
-0.274 \\
0.262\end{array}$ & $\begin{array}{l}0.150 \\
0.060 \\
0.049 \\
0.067\end{array}$ & 0.421 \\
\hline
\end{tabular}

DHEA, Dehydroepiandrosterone; WHR, waist-to-hip ratio.

${ }^{a}$ Independent variables in the regression models have been used either alone or in groups as shown to predict the insulin levels.

${ }^{b} R^{2}$ (the square of the multiple regression coefficient) gives the proportion of the total variation in risk factor levels that is explained by the variables in the model.

${ }^{c}$ ACTH-stimulated cortisol response at $60 \mathrm{~min}$.

${ }^{d}$ ACTH-stimulated DHEA response at $60 \mathrm{~min}$

Table 7. Multiple regression models for the prediction of the smoking status (yes/no) in the study group $(n=44)^{a}$

\begin{tabular}{llcll}
\hline Model & $\begin{array}{l}\text { Independent } \\
\text { variable(s) }\end{array}$ & $\begin{array}{l}\text { Standardized } \\
\text { coefficient } \\
\text { of regression }\end{array}$ & $\begin{array}{l}p \text { value } \\
\text { (two- } \\
\text { tailed) }\end{array}$ & Model $R^{2 \mathrm{~b}}$ \\
\hline 1 & Body mass index & -0.185 & 0.332 & 0.295 \\
& DHEA + 60 & 0.320 & 0.036 & \\
& Fasting insulin & 0.116 & 0.611 & \\
& HDL-cholesterol & -0.212 & 0.213 & \\
& Physical activity & -0.193 & 0.221 & \\
& WHR & -0.034 & 0.834 & 0.278 \\
& DHEA + 60 & 0.324 & 0.036 & \\
& Fasting insulin & -0.010 & 0.961 & \\
& HDL-cholesterol & -0.230 & 0.179 & \\
& Physical activity & -0.231 & 0.137 & \\
\hline
\end{tabular}

DHEA, Dehydroepiandrosterone; WHR, waist-to-hip ratio.

${ }^{2}$ Independent variables in the regression models have been used either alone or in groups as shown to predict the insulin levels.

${ }^{b} R^{2}$ (the square of the multiple regression coefficient) gives the proportion of the total variation in risk factor levels that is explained by the variables in the model.

${ }^{\circ}$ ACTH-stimulated DHEA response at $60 \mathrm{~min}$

ity. These data agree with previous in vitro studies showing that nicotine, and its major metabolite, cotinine can inhibit the activities of 21 - and $11 \beta$-hydroxylases $[5,26]$. Since $11 \beta$-hydroxylase deficiency is usually associated with hypertension [27], and since the blood pressures were 
similar in both groups, inhibition of $11 \beta$-hydroxylase by smoking is a less likely mechanism.

An attempt to exclude potential confounding by matching the subjects for age, BMI, and WHR - variables known to be positively associated with insulin resistance might have introduced a difficult to control for bias, because smokers tend to have higher WHR and lower weight than non-smokers. The two groups also had significant differences in their exercise habits, which might further contribute to the observed metabolic differences. As expected, the physical activity correlated positively with HDLC and negatively with TG. Yet multiple regression analyses suggested that the DHEA response to ACTH stimulation was more important determinant of fasting insulin and TG levels than was the physical activity, even when adjusted for WHR. It was also a significant predictor of the smoking status independent of BMI or WHR, fasting insulin, HDLC, and physical activity. In contrast, after adjustment for smoking the correlation between the DHEA response and TG levels became statistically insignificant. Taken together, these findings suggest that the observed differences in fasting insulin, TG and HDLC levels between these groups are independent of WHR and physical activity at least partly attributable to the smoking-induced adrenal hyperandrogenism.

The relationship between insulin, DHEA, DHEAS, and androstenedione has been a subject of several recent, but partly conflicting studies. Depending on the dose and perhaps on the gender, DHEA may enhance insulin sensitivity [28], have no effect [29], reduce insulin sensitivity, or induce insulin resistance [30]. Supraphysiological concentrations of insulin induced by clamp studies inhibit adrenal 17,20-lyase activity resulting in a decreased DHEA and androstenedione response to ACTH [31]. On the other hand, the production rate of DHEA correlates positively with insulin levels in normal and obese women [32]. Our observations might be most compatible with the possibility that an exaggerated adrenal androgen response to ACTH and an increased secretion of DHEA and androstenedione together with a slightly increased cortisol secretion contribute to the insulin resistance and increased insulin secretion in smokers.

The mechanisms by which smoking affects the HDLCTG balance are relatively unexplored. It is certainly possible that enhanced lipolysis via sympatho-adrenal stimulation [33], and insulin resistance may contribrte to the dyslipidaemia. Nevertheless, our present and previous data suggest, that adrenal androgens may also be involved, possibly through a modulation of the hepatic lipase activity. We, as well as others [6-9], have shown that smoking is associated with elevated basal DHEAS and androstenedione concentrations, but we found no differences in serum testosterone or oestrogen levels [34]. Sex-steroids can modulate HDLC metabolism by at least two mechanisms [35]. Apolipoprotein AI synthesis and HDLC concentrations are increased by oestrogens and decreased by androgens. Furthermore, hepatic lipasemediated degradation of HDLC is decreased by oestrogens and increased by androgens. As far as we know, the significance of adrenal androgens in those processes has not been examined.
In summary, ACTH stimulation tests confirm that smoking is associated with a mild steroidogenic block, which results in increased adrenal androgen production. It appears that adrenal steroids may contribute to the insulin resistance and dyslipidaemia in smokers.

Acknowledgements. We thank Ms A. Samaletdin, Ms I. Wiik, and the personnel of the hormone laboratory at the Department of Clinical Chemistry for skillful technical assistance. This study was supported by grants from the Signe and Ane Gyllenberg Foundation.

\section{References}

1. Friedman GD, Dales LG, Ury HK (1979) Mortality in middle aged smokers and non-smokers. N Engl J Med 300: 213-216

2. Facchini FS, Hollenbeck CB, Jeppesen J, Chen Y-DI, Reaven GM (1992) Insulin resistance and cigarette smoking. Lancet 339: $1128-1130$

3. Craig WY, Palomaki GE, Haddow JE (1989) Cigarette smoking and serum lipid and lipoprotein concentrations: an analysis of published data. BMJ 298: 784-788

4. Reaven GM (1988) Role of insulin resistance in human disease. Diabetes 37: 1595-1607

5. Yeh J, Barbieri RL (1989) Effects of smoking on steroid production, metabolism, and estrogen-related disease. Semin Repr Endocrinol 7:326-334

6. Barrett-Connor E, Khaw K-T, Yen SSC (1986) A prospective study of dehydroepiandrosterone sulphate, mortality, and cardiovascular disease. N Engl J Med 315: 1519-1524

7. Dai WS, Gutai JP, Kuller LH, Cauley JA for the MRFIT Research Group (1989) Cigarette smoking and serum sex hormones in men. Am J Epidemiol 128: 796-805

8. Salvini S, Stampfer MJ, Barbieri RL, Hennekens CH (1992) Effects of age, smoking and vitamins on plasma DHEAS levels: a cross-sectional study in men. J Clin Endocr Metab 74: 139-143

9. Hautanen A, Mänttäri M, Koskinen P, Manninen V, Adlercreutz H, Frick MH (1990) Dehydroepiandrosterone sulphate as a coronary risk factor in the Helsinki Heart Study. Circulation 82: IIIS468 (Abstract)

10. Hill P, Wynder EL (1974) Smoking and cardiovascular disease. Effect of nicotine on the serum epinephrine and corticoids. Am Heart J 87: 491-496

11. Winternitz WW, Quillen D (1977) Acute hormonal response to cigarette smoking. J Clin Pharmacol 17: 389-397

12. Cryer PE, Haymond MW, Santiago JV, Shah SD (1976) Norepinephrine and epinephrine release and adrenergic mediation of smoking-associated hemodynamic and metabolic events. $\mathrm{N}$ Engl J Med 295: 573-577

13. Wilkins JN, Carlson HE, Van Vunakis H, Hill MA, Gritz E, Jarvik ME (1982) Nicotine from cigarette smoking increases circulating levels of cortisol, growth hormone, and prolactin in male chonic smokers. Psychopharmacology-Berl 78: 305-308

14. Rizza RA, Mandarino LJ, Gerich JE (1982) Cortisol-induced insulin resistance in man: impaired suppression of glucose production and stimulation of glucose utilization due to a postreceptor defect of insulin action. J Clin Endocrinol Metab 54: 131-138

15. Bratusch-Marrain PR, Smith D, DeFronzo RA (1982) The effect of growth hormone on glucose metabolism and insulin secretion in man. J Clin Endocrinol Metab 55: 973-978

16. Shamoon H, Hendler R, Sherwin RS (1981) Synergistic interactions among anti-insulin hormones in the pathogenesis of stress hyperglycemia in humans. J Clin Endocrinol Metab 52:1235-1241

17. Björntorp P (1992) Abdominal fat distribution and disease: an overview of epidemiological data. Ann Med 24: 15-18

18. Hypertension Detection and Follow-up Program Cooperative Group (1979) Five-year findings of the hypertension detection and follow-up program. JAMA 242: 2562-2570 
19. Siedel J, Hägele OE, Ziegenhorn J, Wahlefeld AW (1983) Reagent for the enzymatic determination of serum total cholesterol with improved lipolytic efficiency. Clin Chem 29:1075-1080

20. Hautanen A, Sarna S, Pelkonen R, Adlercreutz H (1993) Serum sex-hormone binding globulin, cardiovascular risk factors and adrenal cortisol responses to dexamethasone and adrenocorticotropin. Metabolism 42

21. Finley PR, Schifman RB, Williams RJ, Lichti DA (1972) Cholesterol in high-density lipoprotein: use of $\mathrm{Mg}(2+) /$ dextran sulphate in its enzymic measurement. Clin Chem 18:499-502

22. Kuoppasalmi K, Näveri $H$, Rehunen S, Härkönen $M$, Adlercreutz H (1976) Effect of strenuous anaerobic running exercise on plasma growth hormone, cortisol, luteinizing hormone, testosterone, androstendione, estrone and estradiol. J Steroid Biochem 7: 823-829

23. Hautanen A, Mänttäri M, Manninen V, Frick MH, Adlercreutz $H$ (1992) Effects of gemfibrozil treatment on serum levels of androstanediol glucuronide and adrenal androgens. J Steroid Biochem Molec Biol 42: 433-434

24. Janzon L, Berntorp K, Hanson M, Lindell S-E, Trell E (1983) Glucose tolerance and smoking: a population study of oral and intravenous glucose tolerance test in middle-aged men. Diabetologia 25: 86-88

25. New MI, White PC, Pang S, Dupont B, Speiser PW (1989) The adrenal hyperplasias. In: Scriver CR, Beaudet AL, Sly WS, Valle $\mathrm{D}$ (eds) The metabolic basis of inherited diseases, Vol 2. McGraw-Hill, New York, pp 1881-1917

26. Barbieri RL, Friedman AJ, Osathanondh R (1989) Cotinine and nicotine inhibit human fetal adrenal $11 \beta$-hydroxylase. J Clin Endocr Metab 69: 1221-1224

27. De Simone G, Tommaselli AP, Rossi R et al. (1985) Partial deficiency of adrenal 11-hydroxylase. A possible cause of primary hypertension. Hypertension 7: 204-210

28. Buffington CF, Givens JR, Kitabchi AE (1991) Opposing actions of dehydroepiandrosterone and testosterone on insulin sensitiv- ity. In vivo and in vitro studies of hyperandrogenic females. Diabetes 40: 693-700

29. Nestler JE, Barlascini CO, Clore JN, Blackard WG (1988) Dehydroepiandrosterone reduces serum low density lipoprotein levels and body fat but does not alter insulin sensitivity in normal men. J Clin Endocrinol Metab 66: 57-61

30. Mortola JF, Yen SSC (1990) The effects of oral dehydroepiandrosterone on endocrine-metabolic parameters in postmenopausal women. J Clin Endocrinol Metab 71: 696-704

31. Nestler JE, McClanahan MA, Clore JN, Blackard WG (1992) Insulin inhibits adrenal 17,20-lyase activity in man. J Clin Endocrinol Metab 74: 362-367

32. Farah MJ, Givens JR, Kitabchi AE (1990) Bimodal correlation between the circulating insulin level and the production rate of dehydroepiandrosterone: positive correlation in controls and negative correlation in the polycystic ovary syndrome with acanthosis nigricans. J Clin Endocrinol Metab 70: 1075-1081

33. Muscat JE, Harris RE, Haley NJ, Wynder EL (1991) Cigarette smoking and plasma cholesterol. Am Heart J 121:141-147

34. Hautanen A, Mänttäri M, Kupari M et al. (1993) Cigarette smoking is associated with elevated adrenal androgen response to adrenocorticotropin. J Steroid Biochem Molec Biol (in press)

35. Tikkanen MJ, Nikkilä E (1987) Regulation of hepatic lipase and serum lipoproteins by sex steroids. Am Heart J 113: 562-567

Received: 10 March 1993

and in revised form: 29 June 1993

Dr. A. Hautanen

Department of Clinical Chemistry

University of Helsinki

Haartmaninkatu 4

SF-00290 Helsinki

Finland 